\title{
MENINGKATKAN KESEGARAN JASMANI DENGAN METODE PENUGASAN SENAM INDONESIA BERSATU
}

\author{
ERNA YANTININGSIH \\ Program Studi Pendidikan Jasmani Kesehatan dan Rekreasi \\ STKIP Pamane Talino \\ ernacjdw@gmail.com
}

\begin{abstract}
Abstrak
Olahraga adalah salah satu cara untuk mendapatkan kesehatan sertadapat meningkatkan Kesegaran jasmani seseorang. Olahraga pada dasarkan baik untuk dilakukan oleh semua orang tidak memandang usia maupun jenis kelamin. Perlunya kesadaran berolahraga sejak dini yang terus dilakukan menjadi suatu kebiasaan yang harus dimiliki oleh anak muda saat ini dalam hal ini dibutuhkan usaha yang optimal.Oleh sebab itu, sebaiknya olahraga harus diberikan dan dikenalkan sejak dini sehingga timbulnyasikap sadar anak akan berolahraga sudah tertanam sejak anak usia dini. Kemandirian berolahragan merupakan suatubentuk sikap seseorang untuk melakukan aktifitas fisik atas dasar keinginan diri sendiri sehingga dapat memenuhi kebutuhan Kesegaran jasmani dan kesehatan seseorang serta menghasilkan prestasi olahraga. Senam Indonesia Bersatu merupakansebuah gabungan dari beberapa gerak tubuh yang mana diiringi dengan menggunakan musik. Iringan musik diharapkan dapat membantu untuk menambah motivasi siswa pada saat melakukan suatu gerak tubuh.Metode penugasan dan penggunaan media audiovisual berupa instruksional video ini bertujuan agar anak dapat mempelajari dan melakukan gerakan senam Indonesia Bersatu selaindilakukan di sekolah namun juga dapat dilakukan diluar sekolah. Penelitian ini menggunakan metode penelitian tindakan (action research) dengan desain Kemmis dan Taggart melalui empat tahapan planning, acting, observasi, refleksi. Penelitian tindakan merupakan penelitian mengenai hal-hal yang biasanya terjadi pada suatu kelompok atau masyarakat, sehingga hasilnya langsung dapat rasakan pada masyarakat yang bersangkutan. Berdasarkan dari hasil penelitian, pada siklus pertama tingkat kesegaran jasmani siswa mencapai nilai rata-rata 13,66 dan pada siklus ke dua tingkat kesegaran jasmaninya meningkat mencapai nilai rata-rata 15,91 . Terjadinya peningkatan kesegaran jasmani siswa tiap siklusnya, maka dengan demikian kesegaran jasmani siswa dapat ditingkatkan melalui metode penugasan senam Indonesia Bersatu.
\end{abstract}

Kata kunci: Meningkatkan, Kesegaran Jasmani, Senam Indonesia Bersatu

\section{IMPROVING PHYSICAL FITNESS WITH THE ASSIGNMENT METHOD INDONESIA BERSATU GYMNASTICS}

\begin{abstract}
Sports is one means to obtain health and improve physical fitness. Basically all sports are good for all ages and genders. Efforts to build children's habits to be able to have an awareness of exercising early require a pretty hard effort. Therefore, exercise should be given from children so that the child's independence to be aware of exercise can be implanted early on. Sports independence is an attitude of someone who is full of perseverance to carry out physical activities on his own impulse to meet the needs of health and physical fitness, pursue sports achievements and wish to do physical activities without the help of others. United Indonesia Gymnastics is a combination of body movements accompanied by music. This musical accompaniment is expected to increase students' motivation in doing their body movements. The assignment method and the use of
\end{abstract}


audiovisual media in the form of instructional videos are aimed so that children can learn and do the United Indonesia gymnastics movements not only at school, but can also be done outside of school like at home. This research uses an action research method with Kemmis and Taggart designs through four stages of planning, acting, observing, reflecting. Action research is research about things that happen in the community or target group, and the results can be directly imposed on the community concerned. Based on the results of the study, in the first cycle the level of physical fitness of students reached an average value of 13.66 and in the second cycle the level of physical fitness increased to an average value of 15.91. An increase in physical fitness of students each cycle, then the physical fitness of students can be improved through the United Indonesia gymnastic assignment method.

Keywords: Improve, Physical Fitness, United Indonesian Gymnastics

\section{PENDAHULUAN}

Penjasorkes merupakan salah satu media yang digunakan untuk dapat merangsang pertumbuhan fisik, keterampilan motorik, perkembangan psikis, pengetahuan dan penalaran, penghayatan nilai-nilai (sikap, mental, emosional, sportivitas, spiritual dan juga sosial), serta menerapkan kebiasaan pola hidup sehat yang berpusat untuk mendorong pertumbuhan dan perkembangan psikis dan kualitas fisik yang seimbang.

Fungsi kesegaran jasmani menjadi sangat penting bagi anak termasuk ketika anak sedang berada dalam tingkat Sekolah Menengah Atas (SMA). Hal ini dikarenakan segala aspek perkembangan tubuh sedang berkembang. Perlunya pembinaan tentang peningkatan kesegaran jasmani di lingkungan Sekolah Menengah Atas yang bertujuan untuk menunjang tercapainya proses belajar mengajar yang maksimal, hal ini dikarenakan apabila anak memilikikesegaran jasmani yang cukup baik anak akan dapat melaksanakan kewajiban belajardengan baik, kesimpulannya jika mereka memiliki kesegaran jasmani yang baik maka anak juga dapat melakukan aktifitas seharihari dengan baik pula contohnya pada saat melakukan kegiatan bermain.

Senam Indonesia Bersatu pada hakikatnya termasuk jenis olahraga Kesegaran yang diciptakan dengan tujuan untuk memelihara dan meningkatkan Kesegaran jasmani. Senam Indonesia Bersatu merupakan suatu gabungan dari gerak tubuh yang biasanya diiringi dengan alunan musik. Iringan musik yang digunakan diharapkan dapat menambah minat dan motivasi siswa dalam melakukan gerak. Gerakan pada senam. Indonesia Bersatu ini pun sangat mudah dan dapat dimengerti oleh anak-anak. Kelas XI di SMA Rentawan Jelimpo merupakan sekolah yang terletak di daerah Kabupaten Landak, dan sebagian besar siswa-siswi yang bersekolah di sana berasal dari kalangan keluarga dengan taraf ekonomi menengah ke bawah.

Penerapan metode penugasan dan penggunaan media audio visual berupa instruksional video ini bertujuan agar anak dapat mempelajari dan melakukan gerakan senam Indonesia Bersatu bukan hanya di sekolah tetapi dapat dilakukan di luar sekolah. Selain melihat dan mendengar, orang 
yang menerima pelajaran dapat lebih mudah dan lebih mengerti dengan cepat. Dengan adanya penggunaan media yang berupa video instruksional, siswa dapat melihat dan mengamati secara langsung gerakan apa yang diperagakan oleh instruktur, serta siswa dapat mengulang-ulang kembali gerakan yang diajarkan. Berdasarkan latar belakang masalah tersebut, maka penelitian ini berjudul "Meningkatkan Kesegaran jasmani melalui metode penugasan senam Indonesia Bersatu pada siswa kelas XI SMA Rentawan Jelimpo Kabupaten Landak.

\section{KAJIAN TEORI}

\section{Konsep Penelitian Tindakan}

Pada dasarnya Penelitian merupakan suatu kegiatan yang secara sistematis memiliki tujuan untuk memecahkan masalah dalam penerapan metode ilmiah. Metode yang digunakan dalam penelitian ini yaitu penelitian tindakan (action research). Pengertian penelitian tindakan yaitu penelitian tentang hal-hal yang biasa terjadi di masyarakat/kelompok sasaran. Hasil dari penelitian tindakan akan langsung dapat dirasakan pada masyarakat yang bersangkutan. Karakteristik utama pada penelitian tindakan ini adalah adanya keikutsertaan dan kolaborasi yang terjadi oleh peneliti dengan anggota kelompok sasaran. Penelitian tindakan merujuk pada sebuah tindakan, dimana seorang peneliti melakukan suatu tindakan yang berupa eksperimen, dan secara khusus dilakukan kegiatan mengamati secara terus menerus, untuk dilihat kekurangan dan kelebihannya, kemudian akan diadakan pengubahan secara terkontrol sampai pada akhirnya akan ada upaya maksimal dalam bentuk suatu tindakan yang dianggap paling tepat sesuai dengan pendapat Suharsimi Arikunto, 2011, p. 244.

Penelitian tindakan menurut Kemmis dan Mc Taggart dalam Darmadi, bahwa cara suatu kelompok atau individu dalam mengorganisasi suatu kondisi tertentu sehingga mereka dapat mempelajari adanya berbagai pengalaman yang mereka alami dan membuat pengalaman mereka nantinya dapat diakses oleh orang lain. Pada umumnya penelitian secara praktis sangat cocok untuk meningkatkan kualitas dari subyek yang akan diteliti. Subjek penelitian yang akan diteliti bisa berupa kelas maupun kelompok manapun yang berusaha meningkatkan kualitas kinerja menurut Suwarsih Madya, 2011, p. 25.

\section{Konsep Model Tindakan}

Pendidikan jasmani olahraga dan kesehatan adalah pendidikan yang dilakukan melalui aktivitas fisik di mana hal ini menjadi media utama untuk dapat mencapai tujuan. Siswa sangat membutuhkan Pendidikan jasmani olahraga dan kesehatan untuk dapat membina Kesegaran jasmani, kesehatan dan rohaninya.

Kesegaran jasmani yang prima dibutuhkan oleh anak Sekolah Menengah Atas yang masih gemar bermain karena siswa akan terus aktif dalam aktivitas di sekolah, di rumah, serta lingkungan 
sekitar. Banyak cara yang dapat dilakukan untuk dapat meningkatkan Kesegaran jasmani, salah satunya melalui olahraga senam, karena senam sangat cocok untuk melatih keterampilan gerak anak.

Senam merupakan aktivitas fisik yang sangat kaya struktur gerakannya. Senam mampu membangun secara lengkap berupa gerakan-gerakan dasar yang dapat membangun pola gerak yang sangat lengkap, dimulai dari pola gerak lokomotor, non lokomotor, sampai gerak manipulatif. Dengan Konsep model tindakan yang akan dilakukan untuk dapat meningkatkan kesegaran jasmani yaitu melalui metode penugasan dengan mengikut sertakan siswa putra dan putri kelas XI SMA Rentawan Jelimpo Kabupaten Landak.

\section{Kesegaran Jasmani}

Kesegaran jasmani merupakan kondisi jasmani yang mampu menggambarkan potensi serta kemampuan jasmani seseorang untuk melakukan berbagai tugas tertentu dengan hasil yang maksimal tanpa nampaknya keletihan yang berarti (Widiastuti, 20115:15). Sejalan dengan Widiastuti, Djoko Pekik berpendapat bahwa kesegaran jasmani merupakan kemampuan seseorang dalam melakukan pekerjaan sehari-hari secara efisien dan tanpa menimbulkan kelelahan yang berlebih, sehingga seseorang mampu menikmati waktu luangnya (Djoko Pekik Irianto, 2004:2).

\section{Metode Penugasan}

Guru dalam setiap pembelajaran harus berpusat kepada siswa artinya pembelajaran yang dilakukan menggunakan metode dan pendekatan yang harus disesuaikan dengan keadaan atau kondisi di lapangan. Salah satu metode pembelajaran yang dapat digunakan dalam proses belajar adalah metode penugasan. Metode penugasan biasa disebut metode pemberian tugas atau metode tugas. Menurut Syaiful Sagala, metode penugasan yaitu "cara menyampaikan informasi dalam kegiatan pembelajaran di mana guru akan memberikan suatu tugas tertentu supayasiswa melakukan proses kegiatan belajar dan dipertanggung jawabkan diakhir pembelajaran (Syaiful Sagala, 2003:219). Sedangkan menurut pendapat Syaiful Bahri Djamarah, metode penugasan atau Resitasi adalah "Suatu pekerjaan yang harus anak didik selesaikan tanpa terikat dengan tempat (Syaiful Bahri, 2010:235).

\section{Media Audiovisual}

Media Audio-visual merupakan kombinasi audio dan visual, dimana tidak hanya bertujuan untuk menyampaikan informasi tetapi dapat membentuk perilaku seseorang. Sehingga media audiovisual merupakan media yang bisa dilihat atau diamati dan dapat didengar dari sesuatu yang divisualisasikan menurut Sri Anitah, 2010:48.

Ciri khas pembelajaran menggunakan media audio-visual yakni menggunakan pemakaian perangkat keras selama proses KBM contohnya mesin proyektor film, tape recorder serta proyektor 
visual. Pengajaran dengan menggunakan media audio-visual merupakan produksi serta penggunaan materi yang penyerapan materinya melalui penglihatan dan pendengaran dalam hal ini tidak seluruhnya bergantung pada pemahaman kata/symbol saja (Azhar Arsyad, 2004:30).

Beberapa pendapat di atas menunjukkan bahwa penggunaan media audio-visual adalah suatu cara dalam proses pembelajaran menggunakan sebuah unsur gambar yang dapat dilihat, contoh: rekaman video, film, slide suara, dan lain-lain. Melalui media audio-visual, siswa bisa mengamati dan memahami yang mereka lihat dan dengarapa saja yang diperagakan oleh istruktur. Pembelajaran senam Indonesia Bersatu dengan menggunakan media audio-visual akandapat mempermudah siswa dalam memahami gerakan-gerakan senam misalnya sikap tubuh, gerakan kaki, maupun gerakan lengan yang seharusnya.

\section{METODE PENELITIAN}

Metode penelitian menggunakan metode penelitian tindakan (action research) dengan desain Kemmis dan Taggart. Pelaksanaan dari penelitian ini melibatkan kolaborator yakni rekan sejawat dan pelaksana tindakan yakni guru. Hasil akhir yang didapat dari kegiatan penelitian tindakan adalah upaya meningkatan kesegaran jasmani siswa dengan menggunakan metode penugasan yang berupa senam Indonesia Bersatu.

Prosedur yang ada pada penelitian tindakan ini menggunakan siklus, yang mana setiap siklus memiliki tahapan yang dinilai sistematis. Prosedur dan desain dalam penelitian tindakan ini terdiri dari tahap (1) perencanaan tindakan, (2) pelaksanaan, (3) pengamatan, dan (4) refleksi. Pada tahap refleksi, terdapat peningkatan yang dialami dalam penelitian ini, di mana hal ini disebut sebagai akibat dari intervensi tindakan yang sudah diberikan dan memungkinkan untuk dapat selanjutnya melakukan perencanaan tindakan lanjutan pada siklus berikutnya. Setelah pra penelitian dipersiapkan untuk dilakukan, peneliti melakukan berbagai langkah penelitian tindakan dan dimulai dari siklus I dengan yakni dengan tahapan sebagai berikut: Tahap Perencanaan (Planning) dan tahap Tindakan (acting).

Penugasan senam Indonesia Bersatu ini dilaksanakan di sekolah dan dilakukan juga di rumah. Disetiap akhir siklus I dan siklus berikutnya, dari kegiatan senam Indonesia Bersatu dilakukan evaluasi formatif untuk melihat hasil proses belajar anak dari kegiatan senam Indonesia Bersatu yang telah dilakukan. Skor hasil evaluasi formatif pada setiap akhir pokok bahasan tersebut menjadi salah satu bahan refleksi yang akan dilakukan peneliti bersama kolabolator pada akhir siklus I. Refleksi secara keseluruhan dari siklus I dilakukan oleh peneliti bersama kolabolator pada akhir siklus setelah 4 kali pertemuan, sama halnya dengan siklus II, refleksi juga dilakukan di akhir pertemuan, yaitu pada pertemuan keempat dan kedelapan 


\section{HASIL DAN PEMBAHASAN}

Berdasarkan hasil tes awal TKJI pada usia 14-16 tahun yang dilakukan pada kelas XI SMA Rentawan Jelimpo, pada data awal diperoleh skor minimum yaitu 8 dan skor maksimum 17, dengan rata-rata nilai yaitu 11,47 . Jumlah siswa yang memperoleh nilai rata-rata yaitu 8 orang (25\%), siswa yang memperoleh nilai dibawah rata-rata yaitu sebanyak 17 orang $(53,13 \%)$, dan 7 orang $(21,88 \%)$ yang memperoleh nilai di atas nilai rata-rata.

Dengan demikian sesuai data di atas nilai rata-rata 11,47 tergolong dalam kategori tingkat Kesegaran jasmani kurang. Banyaknya siswa yang mendapatkan nilai di bawah rata-rata menunjukkan bahwa tingkat Kesegaran jasmani siswa masih sangat rendah. Hal ini dapat dipengaruhi oleh beberapa hal diantaranya yaitu kurangnya pendekatan antara guru dan siswa, minat belajar siswa yang juga rendah, serta metode pembelajaran yang diterapkan kurang mendukung materi pelajaran.

\section{Tes Kesegaran Jasmani Indonesia siklus I}

Hasil tes siklus I diperoleh skor minimun yaitu 10, skor maksimum yaitu 17, dengan mendapatkan nilai rata-rata sebesar 13,66. Jumlah siswa yang mendapatkan nilai rata-rata sebanyak 5 orang $(15,63 \%)$, dan siswa yang mendapatkan nilai dibawah nilai rata-rata sebanyak 10 orang $(31,25 \%)$, dan 17 orang $(53,13 \%)$ yang memperoleh nilai di atas nilai rata-rata. Hasil nilai rata-rata 13,66 tergolong dalam kategori tingkat kesegaran jasmani sedang, dengan berkurangnya siswa yang mendapatkan nilai dibawah rata-rata hal ini berarti bahwa kesegaran jasmani siswa sudah mengalami peningkatan dari data awal.

Dengan demikian, sesuai data yang diperoleh dapat dikatakan bahwa kesegaran jasmani siswa sudah mengalami peningkatan dari data awal. Hal ini disebabkan karena metode pembelajaran yang diterapkan masih dalam penyesuaian bagi siswa serta rendahnya semangatnya dalam proses pembelajaran.

\section{Data kualitatif hasil observasi/pengamatan catatan lapangan siklus I}

Berdasarkan data hasil dari catatan lapangan pada siklus I ditemukan bahwa selama proses KBM berlangsung terlihat masih banyak sejumlah siswa yang melakukan kegiatan yang menunjukkan sikap pasif dan masih ada beberapa siswa yang melakukan gerakan yang salah pada gerakan senam Indonesia Bersatu, salah satunya langkah kaki yang tidak berirama, tidak singkronnya antara koordinasi gerakan kaki dan tangan dan kurang seriusnya siswa dalam melakukan gerakan senam Indonesia Bersatu. Hal ini sangat berpengaruh terhadap tingkat Kesegaran jasmani siswa dan jika dilakukan dengan semaunya/asal-asalan, hal ini tidak akan dapat mempengaruhi Kesegaran jasmaninya. 
Berdasarkan data tersebut maka hasil Kesegaran jasmani siswa pada siklus I belum meningkat secara signifikan sesuai dengan target yang diinginkan. Oleh sebab itu, tindakan selanjutnya akan diteruskan pada siklus II.

\section{Tes Kesegaran Jasmani Indonesia siklus II}

Pada siklus ke II ini, perolehan total nilai siswa pada tes Kesegaran jasmani telah mengalami peningkatan dari siklus I. Hasil tes siklus II diperoleh skor minimun yaitu 12, skor maksimum yaitu 21, dan rata-rata nilai mencapai 15,91. Dari data tingkat Kesegaran jasmani siswa yang memperoleh nilai rata-rata sebanyak 7 orang $(21,88 \%)$, siswa yang mendapatkan nilai dibawah nilai rata-rata yaitu sebanyak 14 orang $(43,75 \%)$, dan 11 orang $(34,38 \%)$ yang mmendapatkan nilai di atas nilai rata-rata. Nilai rata-rata 15,91 tergolong dalam kategori tingkat Kesegaran jasmani sedang, dengan banyak nya siswa yang memperoleh nilai di atas rata-rata. Data tersebut menunjukkan adanya peningkatan Kesegaran jasmani siswa pada siklus II. Hal ini berarti bahwa Kesegaran jasmani siswa sudah mengalami peningkatan dari siklus I.

\section{Data Kualitatif hasil pengamatan catatan lapangan siklus II}

Berdasarkan hasil catatan lapangan pada siklus II menunjukkan pada saat pembelajaran berlangsung sejumlah siswa sudah mulai aktif dan serius melakukan senam Indonesia Bersatu, bisa dikatakan hamper semua siswa sudah mulai dapat menguasai gerakan senam Indonesia Bersatu walaupun gerakannya masih belum sempurna, ada beberapa anak yang masih ketinggalan tempo musiknya, dan juga tidak beraturannya koordinasi gerakan kaki dan tangan masih tetapi para siswa sangat bersemangat pada saat melakukan senam Indonesia Bersatu. Hal ini terbukti dengan hasil dari kesesuaian tes Kesegaran jasmani siswa yang semakin lama semakin meningkat.Hal ini dapat disimpulkan bahwa data awal diperoleh skor minimalsebesar 8, skor maksimal 17, dengan rata-rata nilai sebesar 11,47. Pada siklus I terlihat peningkatan skor minimal sebesar 10, skor maksimal 17, dengan rata-rata nilai sebesar 13,66. Selanjutnya pada siklus II telihat adanya peningkatan secara signifikan yaitu perolehan skor minimalsebesar 12 , skor maksimal 21, dengan rata-rata nilai yang mencapai 15,91 . Sehingga dapat disimpulkan bahwa dari sebuah data awal yang diamati jika setelahnya diberikan tindakan pada siklus I dan II mampu meningkatkan kesegaran jasmani siswa pada tiap siklusnya.

\section{KESIMPULAN}

Sesuai dengan hasil penelitian di atas, dapat disimpulkan bahwa terjadi peningkatan Kesegaran jasmani dengan menggunakan metode penugasan yang berupa senam Indonesia Bersatu dan dilaksanakan pada proses pembelajaran pendidikan jasmani terhadap siswa kelas XI SMA Rentawan Jelimpo. 
Pada siklus pertama dan kedua di tahap perencanaan kegiatan pembelajaran kegiatan proses pembelajaran dapat berjalan dengan efektif dengan memberikan arahan kepada siswa sesuai dengan rencana pembelajaran yang telah dibuat. Hasil penelitian pada siklus pertama menunjukkan bahwa gambaran tingkat Kesegaran jasmani siswa kelas XI SMA Rentawan Jelimpo Kabupaten Landak tergolong sedang dengan rata-rata nilai 13,66 dari nilai maksimal 25. Rincian hasil tes adalah jumlah siswa yang mendapatkan nilai di bawah rata-rata yaitu sebanyak 15 orang siswa (46,88\%), dan siswa yang mendapatkan nilai di atas nilai rata-rata yaitu sebanyak 17 orang $(53,13 \%)$.

Dengan berkurangnya jumlah anak yang mendapatkan nilai di bawah rata-rata, hal ini menunjukkan bahwa Kesegaran jasmani anak sudah mengalami peningkatan. Berdasarkan hasil di atas pada siklus pertama siswa cukup antusias dalam melakukan senam segar ceria. Berdasarkan dengan refleksi, harapan yang diinginkan peneliti yakni $80 \%$ siswa bisa aktif dan sangat antusias dalam mengikuti kegiatan pembelajaran, sehingga berpengaruh terhadap peningkatan kesegaran jasmani.

Pada tahap siklus kedua diberikan pengertian dan pengarahan sesuai kondisi siswa pada saat itu. Hasilnya menunjukkan bahwa tingkat kesegaran jasmani siswa telah mengalami peningkatan yang signifikan. Hasil penelitian pada siklus II menunjukkan bahwa nilai rata-rata mencapai 15,91 dan tergolong dalam kategori sedang. Rincian hasil tes yakni jumlah siswayang mendapatkan nilai dibawah rata-rata yaitu sebanyak14 orang siswa $(43,75 \%)$ dan siswa yang mendapatkan nilai di atas nilai rata-rata yaitu sebanyak 18 orang $(56,25 \%)$. Jumlah siswa yang memperoleh nilai di atas rata-rata semakin banyak. Hal ini menunjukkan bahwa Kesegaran jasmani siswa juga mengalami peningkatan. Berdasarkan hasil penelitian, pada siklus pertama tingkat kesegaran jasmani siswa mencapai nilai rata-rata 13,66 dan pada siklus kedua meningkat mencapai nilai rata-rata 15,91 . Oleh karena itu, dapat disimpulkan bahwa kesegaran jasmani siswa dapat ditingkatkan melalui metode penugasan senam Indonesia Bersatu.

\section{DAFTAR PUSTAKA}

Arikunto, Suharsimi (2006). Prosedur Penelitian Suatu Pendekatan Praktik. Jakarta:PT. Rineka Cipta,

Arsyad, Azhar (2004). Media Pembelajaran. Jakarta: Raja Grafindo Persada.

Bompa, Tudor O (2009). Periodization Theory andMethodology of Training.UnitedStates of America.Human Kinetics.

Depdiknas (2010). Pusat Kesegaran Jasmani danRekreasi.Tes Kesegaran Jasmani Indonesia.Jakarta

Jamarah, Syaiful Bahri (2010). Strategi BelajarMengajar. Jakarta: PT Rineka Cipta. 
Lukman Offset, 2000. Geoffrey, E. Mills. Action Research: A Guide For The Teacher Researcher. USA

Kemmis, Stephen and Robin McTaggart (2013). The Action ResearchPlanner.Singapore: Springer, 2014.

Kunarti, Tri Ulan (2013). Pengaruh Latihan Senam Irama terahadap Peningkatan Kesegaran jasmani. FKIP-Universitas Lampung.

Madya, Suwarsih (2011). Teori dan Praktik Penelitian Tindakan (Action Research). Bandung: Alfabeta.

Sagala,Syaiful (2003). Konsep dan MaknaPembelajaran untuk Membantu Memecahkan Problematika Belajar dan Mengajar. Bandung: Alfabeta.

Sukadiyanto (2011). Pengantar Teori dan Metodologi Melatih Fisik.Bandung:Lubuk Agung 